\title{
Level of Readiness of Daily Secondary School Students for Use of Augmented Reality in Form 2 Science Textbooks
}

\author{
Nurhazlina Nordin ${ }^{1}$, Md Yusoff Daud ${ }^{2, *}$ \\ ${ }^{1}$ Department of Textbook and Technologies, Ministry of Education, 98000, Putrajaya, Malaysia \\ ${ }^{2}$ Center for Innovation in Teaching and Learning, Faculty of Education, Universiti Kebangsaan Malaysia, Bangi 43600, Malaysia
}

Received July 30, 2020; Revised October 7, 2020; Accepted October 30, 2020

\section{Cite This Paper in the following Citation Styles}

(a): [1] Nurhazlina Nordin, Md Yusoff Daud, "Level of Readiness of Daily Secondary School Students for Use of Augmented Reality in Form 2 Science Textbooks," Universal Journal of Educational Research, Vol. 8, No. 11A, pp. 17 24, 2020. DOI: 10.13189/ujer.2020.082103.

(b): Nurhazlina Nordin, Md Yusoff Daud (2020). Level of Readiness of Daily Secondary School Students for Use of Augmented Reality in Form 2 Science Textbooks. Universal Journal of Educational Research, 8(11A), 17 - 24. DOI: 10.13189/ujer.2020.082103.

Copyright $\odot 2020$ by authors, all rights reserved. Authors agree that this article remains permanently open access under the terms of the Creative Commons Attribution License 4.0 International License

\begin{abstract}
Augmented reality (AR) applications are an agent of change in how students learn by taking the learning process beyond the physical space of the classroom. AR applications have begun to be integrated into high school textbooks to enable students to visualize real phenomena from the textbooks to enhance the learning experience. This study sought to determine the level of readiness of daily secondary school students for the use of AR applications in Form 2 science textbooks. The findings indicate a high level of readiness among students to use AR applications (mean=3.92, SD=.439), and a moderate level of hindrance in $\mathrm{AR}$ applications (mean=3.17, $\mathrm{SD}=.652$ ). Pearson correlation tests of the relationships among all of the variables suggested that the use of AR applications would be acceptable among secondary school students. This study provides an important indicator that the future educational environment in Malaysia must take into account and integrate elements of the latest technology. Educational institutions must move forward innovatively and adapt to aspects related to the curriculum and learning infrastructure creatively.
\end{abstract}

Keywords Augmented Reality, Readiness, Hindrance, Science Texts Book

\section{Introduction}

Malaysia is a fast growing and proactive country in line with the boom of globalization today. To ensure high economic performance, the country needs a dynamic, proactive, and competitive workforce. Facing the increasingly challenging waves of change, the country needs a paradigm shift that could help make the economy more resilient and stable in tandem with developed countries, thus forming a successful and competent nation. To achieve this, Malaysia needs to produce a generation that is competitive, creative, rational, and capable of bringing about change in various aspects, especially in the field of education and technology related to the Industrial Revolution 4.0 (IR 4.0). Based on appearance of the IR 4.0 in mid-2016, the government formulated a policy framework that outlines a comprehensive action plan covering strategies and programs in various fields, including education [1]. The IR 4.0 is based on advances in the fields of autonomous robots, big data, augmented reality, artificial intelligence, cloud computing, internet of things, smart sensors, digital system integration, 3D printing, simulation and cyber security, which have begun to be integrated into national education systems through cooperation between educational and industrial institutions. This goal coincides with the initiative of the Ministry of Education Malaysia (MOE) to improve the education 
system, through the Malaysia Education Blueprint (MEB) 2013-2025, which includes the policy of using information and communication technologies (ICTs) to improve the quality of learning in Malaysia [2].

The development of technology has changed methods of learning among students throughout the world. It has taken the learning process beyond the classroom space and made it more global in nature. The transformation of the use of ICT shows that the Malaysian government is committed to increasing the impact of student learning [3]. Through the latest technological approaches, the learning environment is becoming more attractive, which has indirectly motivated students to learn further, thus contributing to better educational outcomes [4] and further expanding the use of wireless computing technology and mobile devices [5].

Current learning scenarios encourage students to be more inclined to self-learning, self-access, and self-paced education. This is because the students who are in schools today are composed of generation $\mathrm{Z}$-also called the iGeneration, internet generation, or net generation [6]. It is also driven by the existence of a system that can record all learning activities through the use of digital materials and materials obtained online. These elements are a new trend for teaching and learning in schools in the $21^{\text {st }}$ century. Along with the use of smartphones, teachers are being asked to design active learning experiences by involving real-world problems and project activities that can engage students, as well as supporting learning that is more democratic, flexible, autonomous, and comprehensive, both formally and informally [7]. The advent of smart technology in various applications can help the teaching and facilitation process; one of the applications used is augmented reality (AR). AR applications allow students to see real-world environments with digital information overlapping at the same time to enhance the experience [8]. The use of AR applications can help learning activities be carried out collaboratively, support memory-related learning activities, and enable personal and self-oriented learning [9]. In the IR 4.0 Policy Framework, the government of Malaysia has stressed the importance of AR in the delivery of information and learning today. The Ministry of Education has begun to integrate the application of AR with school textbooks as an added value element [10].

\section{Research Background and Problems}

Students' motivation and involvement in learning are often associated with the difficulty of the subject [11]. Although there are various technologies that have been applied in the field of education, there are still students who have difficulty in understanding the learning content of the subject. People have different desires and preferences when choosing new smart gadgets to use. These desires are mainly rooted in gender, personality, interest, values, and social status [12]. Use is dependent on accessibility, ease of use, availability, and flexibility for its adaption to different contexts [13]. Most students have difficulty understanding complex concepts and need strong visualization [14], especially in science subjects. AR applications have great potential because they are able to represent phenomena visually in three dimensions [15]. However, in Malaysia, this AR technology has not yet been widely applied [16]. The AR application integrated into the Form 2 Science textbook is a new element created by the MOE. Studies related to the level of readiness for the acceptance of this new technology are still limited. There have been several studies related to AR application development [17], level of understanding and interest [18], measurement of cognitive load, motivation and attitude [19], as well as the application of AR in biology textbooks [20]. This study therefore sought to identify the level of readiness of daily secondary school students in the Malaysian context for the use of AR applications in Form 2 Science textbooks using the unified theory of acceptance and use of technology (UTAUT) model. The UTAUT model includes four main constructs: performance expectancy (3 items), effort expectancy (4 items), social influence ( 3 items) and facilitating conditions (4 items). These were tested as a direct determinant of intention and behavior to use a technology [21-24]. Three simplification factors were used: gender, duration of device usage, and device ownership. This study also sought to identify to what extent the relationship level of readiness related to hindrance faced in the use of AR applications (8 items).

\section{Research Objectives}

\subsection{The Objectives of the Study are as Follows:}

a). Identify student readiness levels (performance expectations, effort expectations, social influence, and facility condition) and hindrances to using AR applications.

b). Measure differences in students' levels of readiness to use AR applications based on gender, duration of device usage, and level of device ownership

c). Measure the relationship between readiness level and hindrances faced by students in the use of $\mathrm{AR}$ applications

\subsection{Hypothesis}

The study tested the following hypotheses:

- $\mathrm{Ho}^{1}$ : there was no significant difference between the levels of readiness to use AR applications based on gender.

- $\mathrm{Ho}^{2}$ : There was no significant difference between the readiness levels for AR application use based on the duration of device usage. 
- $\mathrm{Ho}^{3}$ : There is no significant difference between the levels of readiness to use AR applications based on device ownership.

- $\mathrm{Ho}^{4}$ : There is no significant difference between the level of readiness and the hindrances faced by students in the use of AR applications

\section{Research Methodology}

This study was a quantitative survey using questionnaires. Data were analyzed using SPSS Version 23. The population of this study was a total of 3,137 Form 2 students in daily secondary school under the MOE in Sepang district, Selangor [25]. The Sepang district in Selangor was chosen because of the number of schools using the science textbook with integrated AR applications. A total of 346 samples were selected, based on the sample determination schedule [26]. This study uses a simple random group sampling method by selecting six of the ten secondary schools in Sepang district, Selangor, following the selection guidelines of 50\%-60\% for random groups [27]. Questionnaire items were constructed and modified and pilot tests were conducted to determine the value of Cronbach's alpha $[23,28,29]$. Items were scored on a 5 -point Likert scale ranging from 1 , strongly disagree, to 3 , undecided, to 5, strongly agree. For the purpose of analyzing the students' level of readiness, results were interpreted according to the mean score, shown in Table 1 [30].

Table 1. Mean Score Interpretation

\begin{tabular}{|c|c|}
\hline Mean Score & Interpretation \\
\hline $1.00-2.34$ & Low \\
\hline $2.35-3.67$ & Moderate \\
\hline $3.68-5.00$ & High \\
\hline
\end{tabular}

A pilot study was conducted with 32 Form 2 students from a secondary school in Nilai Negeri Sembilan district. The Cronbach's alpha value for all items was $0.868,(>0.7)$, which shows a high level of reliability [27,31]. Skewness and kurtosis normality tests indicate that it was normally distributed, with variable test results between \pm 2.5 for statistic and standard error (Table 2).

Table 2. Normal Distribution

\begin{tabular}{|c|c|c|c|c|}
\hline \multirow{2}{*}{ Variable } & \multicolumn{2}{|c|}{ Skewness } & \multicolumn{2}{c|}{ Kurtosis } \\
\cline { 2 - 5 } & Statistic & $\begin{array}{c}\text { Std. } \\
\text { Error }\end{array}$ & Statistic & $\begin{array}{c}\text { Std. } \\
\text { Error }\end{array}$ \\
\hline Students' Level of Readiness & -.073 & .131 & .010 & .261 \\
\hline Performance expectations & .016 & .131 & -.755 & .261 \\
\hline Effort expectations & -.146 & .131 & -.157 & .261 \\
\hline Social influence & .200 & .131 & .019 & .261 \\
\hline Facility conditions & .268 & .131 & -.774 & .261 \\
\hline $\begin{array}{c}\text { Hindrances encountered by } \\
\text { students in the use of AR } \\
\text { applications }\end{array}$ & -.513 & .131 & -.974 & .261 \\
\hline
\end{tabular}

\section{Results and Discussion}

\subsection{Respondent Demographics}

The demographic distribution of respondents is shown in Table 3.

Table 3. Demographic distribution of respondents

\begin{tabular}{|c|c|c|}
\hline & Number & Percentage (\%) \\
\hline Gender & & \\
\hline Male & 105 & 30.3 \\
\hline Female & 241 & 69.7 \\
\hline $\begin{array}{c}\text { Duration of use of mobile } \\
\text { devices }\end{array}$ & & \\
\hline Less than 1 year & 99 & 28.6 \\
\hline 2-3 years & 174 & 50.3 \\
\hline 4-5 years & 73 & 21.1 \\
\hline Mobile device ownership level & & \\
\hline Own & 205 & 59.2 \\
\hline Belongs to Mother & 103 & 29.8 \\
\hline Belongs to Father & 38 & 11.0 \\
\hline
\end{tabular}

\subsection{Students' Level of Readiness to Use AR Applications}

Table 4 shows students' level of readiness to use AR applications according to the four constructs, all of which are at a high level: performance expectations (mean $=3.75$, $\mathrm{SD}=.679$ ); effort expectations (mean $=3.75, \mathrm{SD}=.663$ ); social influence (mean=3.97, $\mathrm{SD}=.441$ ); and facility conditions (mean $=4.21, \mathrm{SD}=.440$ ). Overall, the mean score for students' level of readiness is high (mean=3.92, $\mathrm{SD}=.439)$.

Table 4. The level of readiness of students to use AR application

\begin{tabular}{|c|c|c|c|}
\hline Construct & Mean & SD & Level \\
\hline Performance expectations & 3.75 & .679 & High \\
\hline Effort expectations & 3.75 & .663 & High \\
\hline Social influence & 3.97 & .441 & High \\
\hline Facility conditions & 4.21 & .440 & High \\
\hline Overall & 3.92 & .439 & High \\
\hline
\end{tabular}

\subsubsection{Performance expectations}

Table 5 shows the frequency, percentage, mean, and standard deviation scores for each expected performance item. The results indicate that two items had high scores, while another item had a moderate score. Based on the findings of this study, item B1-"I found the use of $A R$ effective for the latest teaching and learning sessions"recorded the highest mean (mean=3.88, $\mathrm{SD}=.558$ ), while B2- "The use of AR helps me understand the topic quickly" had the lowest mean (mean=3.50, SD=.930). The overall performance expectations score was high (mean $=3.75$, $\mathrm{SD}=.679$ ). 
Table 5. Performance Expectations

\begin{tabular}{|c|c|c|c|c|c|c|c|c|}
\hline No & Statement & SDA & DA & UD & A & SA & Mean & SD \\
\hline B1 & $\begin{array}{c}\text { I found the use of AR effective for the latest } \\
\text { teaching and learning sessions. }\end{array}$ & - & - & $\begin{array}{c}76 \\
(22.0)\end{array}$ & $\begin{array}{c}234 \\
(67.6)\end{array}$ & $\begin{array}{c}36 \\
(10.4)\end{array}$ & 3.88 & .558 \\
\hline B2 & $\begin{array}{c}\text { The use of this AR helps me understand the } \\
\text { topic quickly. }\end{array}$ & - & $\begin{array}{c}70 \\
(20.2)\end{array}$ & $\begin{array}{c}70 \\
(20.2)\end{array}$ & $\begin{array}{c}170 \\
(49.1)\end{array}$ & $\begin{array}{c}36 \\
(10.4)\end{array}$ & 3.50 & .930 \\
\hline B3 & $\begin{array}{c}\text { The use of this AR can increase my ideas or } \\
\text { creativity. }\end{array}$ & - & $\begin{array}{c}35 \\
(10.1)\end{array}$ & $\begin{array}{c}42 \\
(12.1)\end{array}$ & $\begin{array}{c}199 \\
(57.5)\end{array}$ & $\begin{array}{c}70 \\
(20.2)\end{array}$ & 3.88 & .846 \\
\hline & Total & & & & & 3.75 & .679 \\
\hline
\end{tabular}

Table 6. Effort Expectations

\begin{tabular}{|c|c|c|c|c|c|c|c|c|}
\hline No & Statement & SDA & DA & UD & A & SA & Mean & SD \\
\hline C1 & $\begin{array}{c}\text { Learning through the use of AR is } \\
\text { easy. }\end{array}$ & - & $\begin{array}{c}35 \\
(10.1)\end{array}$ & $\begin{array}{c}100 \\
(28.9)\end{array}$ & $\begin{array}{c}175 \\
(50.6)\end{array}$ & $\begin{array}{c}36 \\
(10.4)\end{array}$ & 3.61 & .806 \\
\hline C2 & $\begin{array}{c}\text { The content of the topic using AR } \\
\text { is clear and easy to understand. }\end{array}$ & - & - & $\begin{array}{c}140 \\
(40.5)\end{array}$ & $\begin{array}{c}169 \\
(48.8)\end{array}$ & $\begin{array}{c}37 \\
(10.7)\end{array}$ & 3.70 & .651 \\
\hline C3 & $\begin{array}{c}\text { Topic content that uses AR is easy } \\
\text { to use. }\end{array}$ & - & - & $\begin{array}{c}76 \\
(22.0)\end{array}$ & $\begin{array}{c}197 \\
(56.9)\end{array}$ & $\begin{array}{c}73 \\
(21.1)\end{array}$ & 3.99 & .657 \\
\hline C4 & $\begin{array}{c}\text { Learning a topic using AR can } \\
\text { enhance my skills on the subject. }\end{array}$ & - & $\begin{array}{c}36 \\
(10.4)\end{array}$ & $\begin{array}{c}72 \\
(20.8)\end{array}$ & $\begin{array}{c}201 \\
(58.1)\end{array}$ & $\begin{array}{c}37 \\
(10.7)\end{array}$ & 3.69 & .798 \\
\hline & Total & & & & & 3.75 & .663 \\
\hline
\end{tabular}

Table 7. Social Influence

\begin{tabular}{|c|c|c|c|c|c|c|c|c|}
\hline No & Statement & SDA & DA & UD & A & SA & Mean & SD \\
\hline D1 & $\begin{array}{c}\text { Individuals who are important in my life } \\
\text { (whether teachers or parents or guardians } \\
\text { or friends) think that I need to learn using } \\
\text { AR. }\end{array}$ & - & - & $\begin{array}{c}85 \\
(24.6)\end{array}$ & $\begin{array}{c}174 \\
(50.3)\end{array}$ & $\begin{array}{c}87 \\
(25.1)\end{array}$ & 4.01 & .706 \\
\hline D2 & $\begin{array}{c}\text { Individuals who greatly influence my } \\
\text { behavior (whether teachers or parents or } \\
\text { guardians or friends) think I need to learn } \\
\text { using AR. }\end{array}$ & - & - & $\begin{array}{c}73 \\
(21.1)\end{array}$ & $\begin{array}{c}234 \\
(67.6)\end{array}$ & $\begin{array}{c}39 \\
(11.3)\end{array}$ & 3.90 & .561 \\
\hline D3 & $\begin{array}{c}\text { Individuals whose views I welcome } \\
\text { (whether teachers or parents or guardians } \\
\text { or friends) are happy when I use AR in my } \\
\text { learning. }\end{array}$ & - & - & $\begin{array}{c}40 \\
(11.6)\end{array}$ & $\begin{array}{c}270 \\
(78.0)\end{array}$ & $\begin{array}{c}36 \\
(10.4)\end{array}$ & 3.99 & .469 \\
\hline & Total & & & & & & 3.97 & .441 \\
\hline
\end{tabular}

\subsubsection{Effort expectations}

Table 6 shows the frequency, percentage, mean, and standard deviation scores for each item of effort expectation. The results showed that three items had a high score, while another item had a moderate score. Based on the findings of this study, item C3-"Topic content that uses AR easy to use"-recorded the highest mean (mean=3.99, $\mathrm{SD}=.657$ ), while item C1- "Learning through the use of AR is easy"-had the lowest mean (mean=3.61, SD=.806). The overall effort expectations score was high $($ mean $=3.75, \mathrm{SD}=.663)$.

\subsubsection{Social influence}

Table 7 shows the frequency, percentage, mean, and standard deviation scores for each item of social influence. All three items had high scores. Based on the findings of this study, item D1- “Individuals who are important in my life (whether teachers or parents or guardians or friends) think that I need to learn using $A R^{\prime \prime}$-recorded the highest mean (mean=4.01, $\mathrm{SD}=.706)$, while item D2- "Individuals who greatly influence my behavior (whether teachers or parents or guardians or friends) think I need to learn using $A R$ "- - had the lowest (mean=3.90, $\mathrm{SD}=.561)$. The overall social influence score was high (mean=3.97, $\mathrm{SD}=0.441$ ).

\subsubsection{Facility conditions}

Table 8 shows the frequency, percentage, mean, and standard deviation scores for each facility condition item. All four items had high scores. Item E1- "I have the necessary resources (whether mobile device or iPad or tabs) to use AR in my learning"-recorded the highest mean (mean=4.51, $\mathrm{SD}=.501)$, while item E2- "I have the knowledge needed to use AR in my learning" recorded the lowest (mean=3.90, $\mathrm{SD}=.688$ ). The overall facility condition score was high (mean=4.21, $\mathrm{SD}=.440)$. 
Table 8. Facility Conditions

\begin{tabular}{|c|c|c|c|c|c|c|c|c|}
\hline No & Statement & SDA & DA & UD & A & $\mathrm{SA}$ & Mean & SD \\
\hline E1 & $\begin{array}{c}\text { I have the resources needed (either mobile } \\
\text { devices or iPads or tabs) to use AR in my } \\
\text { learning. }\end{array}$ & - & - & - & $\begin{array}{c}169 \\
(48.8)\end{array}$ & $\begin{array}{c}177 \\
(51.2)\end{array}$ & 4.51 & .501 \\
\hline E2 & $\begin{array}{l}\text { I have the knowledge needed to use AR in my } \\
\text { learning. }\end{array}$ & - & - & $\begin{array}{c}101 \\
(29.2) \\
\end{array}$ & $\begin{array}{c}179 \\
(51.7) \\
\end{array}$ & $\begin{array}{c}66 \\
(19.1) \\
\end{array}$ & 3.90 & .688 \\
\hline E3 & $\begin{array}{l}\text { The use of AR is appropriate / compatible } \\
\text { with other technologies (either devices, } \\
\text { applications, or operating systems) that I use. }\end{array}$ & - & - & - & $\begin{array}{c}267 \\
(77.2)\end{array}$ & $\begin{array}{c}79 \\
(22.8)\end{array}$ & 4.23 & .420 \\
\hline E4 & $\begin{array}{l}\text { I can get help from others when having } \\
\text { difficulty using AR. }\end{array}$ & - & - & $\begin{array}{c}38 \\
(11.0) \\
\end{array}$ & $\begin{array}{c}201 \\
(58.1) \\
\end{array}$ & $\begin{array}{c}107 \\
(30.9) \\
\end{array}$ & 4.20 & .617 \\
\hline & Total & & & & & & 4.21 & .440 \\
\hline
\end{tabular}

Table 9. Hindrance encountered by students in the use of AR applications

\begin{tabular}{|c|c|c|c|c|c|c|c|c|}
\hline No & Statement & SDA & DA & UD & A & SA & Mean & SD \\
\hline F1 & $\begin{array}{c}\text { Low internet / Wi-Fi coverage } \\
\text { source. }\end{array}$ & $\begin{array}{c}32 \\
(9.2)\end{array}$ & $\begin{array}{c}75 \\
(21.7)\end{array}$ & $\begin{array}{c}37 \\
(10.7)\end{array}$ & $\begin{array}{c}138 \\
(39.9)\end{array}$ & $\begin{array}{c}64 \\
(18.5)\end{array}$ & 3.37 & 1.263 \\
\hline F2 & $\begin{array}{c}\text { Lack of understanding of the use of } \\
\text { AR in textbooks. }\end{array}$ & $\begin{array}{c}1 \\
(0.3)\end{array}$ & $\begin{array}{c}75 \\
(21.7)\end{array}$ & $\begin{array}{c}67 \\
(19.4)\end{array}$ & $\begin{array}{c}202 \\
(58.4)\end{array}$ & $\begin{array}{c}1 \\
(0.3)\end{array}$ & 3.37 & .831 \\
\hline F3 & Equipment to use AR is incomplete. & $\begin{array}{c}5 \\
(1.4)\end{array}$ & $\begin{array}{c}103 \\
(29.8)\end{array}$ & $\begin{array}{c}38 \\
(11.0)\end{array}$ & $\begin{array}{c}164 \\
(47.4)\end{array}$ & $\begin{array}{c}36 \\
(10.4)\end{array}$ & 3.36 & 1.059 \\
\hline F4 & $\begin{array}{c}\text { Unable to fully commit to using AR } \\
\text { in learning. }\end{array}$ & $\begin{array}{c}1 \\
(0.3)\end{array}$ & $\begin{array}{c}103 \\
(29.8)\end{array}$ & $\begin{array}{c}66 \\
(19.1)\end{array}$ & $\begin{array}{c}174 \\
(50.3)\end{array}$ & $\begin{array}{c}2 \\
(0.6)\end{array}$ & 3.21 & .891 \\
\hline F5 & $\begin{array}{c}\text { There is no self-motivation to use } \\
\text { AR in learning. }\end{array}$ & $\begin{array}{c}1 \\
(0.3)\end{array}$ & $\begin{array}{c}101 \\
(29.2)\end{array}$ & $\begin{array}{c}209 \\
(60.4)\end{array}$ & $\begin{array}{c}35 \\
(10.1)\end{array}$ & $\begin{array}{c}0 \\
(0.0)\end{array}$ & 2.80 & .606 \\
\hline F6 & $\begin{array}{c}\text { AR material in textbooks is not } \\
\text { interesting or is boring. }\end{array}$ & $\begin{array}{c}2 \\
(0.6)\end{array}$ & $\begin{array}{c}104 \\
(30.1)\end{array}$ & $\begin{array}{c}141 \\
(40.8)\end{array}$ & $\begin{array}{c}63 \\
(18.2)\end{array}$ & $\begin{array}{c}36 \\
(10.4)\end{array}$ & 3.08 & .958 \\
\hline F7 & $\begin{array}{c}\text { There are no clear instructions for } \\
\text { using AR in textbooks. }\end{array}$ & $\begin{array}{c}36 \\
(10.4)\end{array}$ & $\begin{array}{c}8 \\
(2.3)\end{array}$ & $\begin{array}{c}198 \\
(57.2)\end{array}$ & $\begin{array}{c}103 \\
(29.8)\end{array}$ & $\begin{array}{c}1 \\
(0.3)\end{array}$ & 3.07 & .863 \\
\hline F8 & $\begin{array}{c}\text { AR is only available in certain } \\
\text { topics. }\end{array}$ & $\begin{array}{c}31 \\
(9.0)\end{array}$ & $\begin{array}{c}35 \\
(10.1)\end{array}$ & $\begin{array}{c}148 \\
(42.8)\end{array}$ & $\begin{array}{c}131 \\
(37.9)\end{array}$ & $\begin{array}{c}1 \\
(0.3)\end{array}$ & 3.10 & .917 \\
\hline & Total & & & & & & 3.17 & .652 \\
\hline
\end{tabular}

\subsection{Hindrances Encountered by Students in the Use of AR applications}

Table 9 shows the hindrances faced by students in the use of AR applications. All eight items had a moderate score. Item F1— "Low internet/Wi-Fi coverage source" had the highest mean (mean=3.37, $\mathrm{SD}=1.263$ ), while item F5- "No self-motivation to use AR in learning" had the lowest (mean=2.80, $\mathrm{SD}=.606)$. The overall score for hindrances was moderate (mean=3.17, $\mathrm{SD}=.652$ ).

\subsection{Differences in Student Readiness to Use AR Applications Based on Gender}

The results of the t-test for the null hypothesis $\mathrm{Ho}^{1}$ is shown in Table 10.

Table 10. T-test, Differences in Students' Level of Readiness to use AR applications Based on Gender

\begin{tabular}{|c|c|c|c|c|c|c|}
\hline & Gender & $\mathrm{N}$ & Mean & SD & t-value & Sig. \\
\hline $\begin{array}{c}\text { Level of Readiness } \\
\text { of Students }\end{array}$ & Male & 105 & 3.99 & .282 & 2.383 & .018 \\
\cline { 2 - 7 } & Female & 241 & 3.89 & .490 & & \\
\hline
\end{tabular}

There was a significant difference in students' level of readiness to use AR applications based on gender $[t=2.383$, $\mathrm{p}=0.018$ ]. Therefore, $\mathrm{Ho}^{1}$ is rejected. These findings also show male students tend to have a higher level of readiness (mean $=3.99, \mathrm{SD}=.282$ ) than female students (mean=3.89, $\mathrm{SD}=.490)$.

\subsection{Differences Student Readiness to us AR Applications Based on the Duration of Device Use}

The ANOVA test was used to test the null hypothesis $\mathrm{Ho}^{2}$; the results are shown in Table 11.

Table 11. One-way ANOVA tests of Differences in Student Readiness to use AR Application Based on Device Usage Period

\begin{tabular}{|c|c|c|c|c|c|c|}
\hline \multicolumn{2}{|c|}{} & $\begin{array}{c}\text { Sum of } \\
\text { Squares }\end{array}$ & df & $\begin{array}{c}\text { Mean } \\
\text { Square }\end{array}$ & F & Sig. \\
\hline \multirow{2}{*}{$\begin{array}{c}\text { Level of } \\
\text { Readiness } \\
\text { of } \\
\text { Student }\end{array}$} & $\begin{array}{c}\text { Between } \\
\text { Groups }\end{array}$ & 31.531 & 2 & 15.766 & 154.110 & .000 \\
\cline { 2 - 7 } & In & 35.089 & 343 & .102 & & \\
\cline { 2 - 8 } & Total & 66.620 & 345 & & & \\
\hline
\end{tabular}

There appears to be a significant difference in students' level of readiness to use AR applications based on duration of device use $[\mathrm{F}(2,343)=154.110, \mathrm{p}=0.000]$. Therefore, $\mathrm{Ho}^{2}$ is rejected. Next, a Scheffé post-hoc test was conducted to identify the level of readiness of students to use the AR applications in the Form 2 Science textbook based on the duration of device use. The test results are shown in Table 12. 
Table 12. Post-Hoc Scheffé Test of Student Readiness to Use AR Application Based on Duration of Device Use

\begin{tabular}{|c|c|c|c|c|c|c|c|}
\hline \multicolumn{2}{|c|}{} & $\mathrm{N}$ & Mean & SD & $\begin{array}{c}\text { Less 1 } \\
\text { year }\end{array}$ & $\begin{array}{c}2-3 \\
\text { years }\end{array}$ & $\begin{array}{c}4-5 \\
\text { years }\end{array}$ \\
\hline \multirow{4}{*}{$\begin{array}{c}\text { Level of } \\
\text { Readiness of } \\
\text { Student }\end{array}$} & $\begin{array}{c}\text { Less 1 } \\
\text { year }\end{array}$ & 99 & 3.80 & .246 & & .063 & $-.697 *$ \\
\cline { 2 - 7 } & $2-3$ years & 174 & 3.74 & .368 & -.063 & & $-.760 *$ \\
\cline { 2 - 7 } & $4-5$ years & 73 & 4.50 & .283 & $.697 *$ & $.760^{*}$ & \\
\hline
\end{tabular}

$* \mathrm{p}<0.05$

The results of the Scheffé post-hoc test indicate that there is a significant mean difference of $\mathrm{p}<0.05$ in students' level of readiness to use AR applications between those who have used their device for 4-5 years (mean $=4.50$, $\mathrm{SD}=.283)$ or less than 1 year $($ mean $=3.80, \mathrm{SD}=.246)$ and those with $2-3$ years of device use (mean=3.74, $\mathrm{SD}=.368$ ).

\subsection{Differences in Student Level of Readiness to Use AR Applications Based on Device Ownership}

The ANOVA test was used to test the null hypothesis $\mathrm{Ho}^{3}$, and the results are shown in Table 13 .

The results of the one-way ANOVA in Table 5.6 indicate that there is a significant difference in student readiness based on device ownership $[\mathrm{F}(2,343)=116.414$, $\mathrm{p}=0.000]$. Therefore, $\mathrm{Ho}^{3}$ is rejected. Next, a Scheffé post-hoc test was conducted to identify students' level of readiness based on device ownership. The test results are shown in Table 14.
The results of the Scheffé post-hoc test indicate that there is a significant mean difference of $p<0.05$ in students' level of readiness to use AR applications based on device ownership.

Table 13. One-Way ANOVA for Student Readiness Based on Device Ownership

\begin{tabular}{|c|c|c|c|c|c|c|}
\hline \multicolumn{2}{|c|}{} & $\begin{array}{c}\text { Sum of } \\
\text { Squares }\end{array}$ & df & $\begin{array}{c}\text { Mean } \\
\text { Square }\end{array}$ & F & Sig \\
\hline \multirow{2}{*}{$\begin{array}{c}\text { Level of } \\
\text { Readiness } \\
\text { of } \\
\text { Student }\end{array}$} & $\begin{array}{c}\text { Between } \\
\text { Groups }\end{array}$ & 26.937 & 2 & 13.469 & 116.414 & .000 \\
\cline { 2 - 7 } & $\begin{array}{c}\text { In } \\
\text { Group }\end{array}$ & 39.683 & 343 & .116 & & \\
\hline Total & 66.620 & 345 & & & \\
\hline
\end{tabular}

\subsection{Hindrances to the Use of AR}

Pearson Correlation analysis was used to test the null hypothesis $\mathrm{Ho}^{4}$, and the results are shown in Table 15; data from Table 9 were recorded before running the analysis.

The results indicate that performance expectations $(\mathrm{r}=0.287, \mathrm{p}<0.01)$, effort expectations ( $\mathrm{r}=0.174, \mathrm{p}<0.01)$, and social influence $(\mathrm{r}=0.419, \mathrm{p}<0.01)$ had a significant relationship to the hindrances encountered by students in the use of AR applications. However, the condition of facilities $(\mathrm{r}=0.049, \mathrm{p}>0.05)$ did not. Overall, as shown in Table 5.7 shows the students' overall level of readiness $(r=0.269, p<0.01)$, as shown in Table 5.7, has a significant relationship with the hindrances encountered, so $\mathrm{Ho}^{4}$ is rejected.

Table 14. Post-Hoc Scheffé Test of Student Readiness Based on Device Ownership

\begin{tabular}{|c|c|c|c|c|c|c|c|}
\hline & & $\mathrm{N}$ & Mean & $\mathrm{SD}$ & Own & $\begin{array}{c}\text { Belongs to } \\
\text { Mother }\end{array}$ & Belongs to Father \\
\hline \multirow{3}{*}{$\begin{array}{c}\text { Level of Readiness of } \\
\text { Student }\end{array}$} & Own & 205 & 3.86 & .402 & - & $.113^{*}$ & $-.840 *$ \\
\hline & Belongs to Mother & 103 & 3.75 & .235 & $-.113 *$ & - & $-.953 *$ \\
\hline & Belongs to Father & 38 & 4.70 & .178 & $.840^{*}$ & $.953 *$ & - \\
\hline
\end{tabular}

$* \mathrm{p}<0.05$

Table 15. Student Readiness and Hindrances Encountered to the Use of AR Applications

\begin{tabular}{|c|c|c|}
\hline & \multicolumn{2}{|c|}{ Hindrance Encountered } \\
\cline { 2 - 3 } & $\mathrm{r}$ & Sig. P \\
\hline Performance Expectations & $-.287^{* *}$ & .000 \\
\hline Effort Expectations & $-.174^{* *}$ & .001 \\
\hline Social Influence & $-.419^{* *}$ & .000 \\
\hline Facility Conditions & .049 & .364 \\
\hline Students' level of readiness to use the AR application & $-.269^{* *}$ & .000 \\
\hline
\end{tabular}

\footnotetext{
$* * \mathrm{p}<0.01$
} 


\section{Conclusions}

The findings of this study show students have a high level of readiness to use the AR application in the Form 2 science textbooks (mean=3.92, $\mathrm{SD}=.439)$, which may be a good indicator of students' readiness to use other new technologies. This may have to do with the latest generation (generation Z) being exposed to information anywhere and at any time. Although the gender differences slightly favor male students, this should not be overemphasized, as it contradicts a previous study that these are not significant for AR features in chemistry lessons [32]. Students' skills, confidence, and comfort with learning resources can influence their readiness for online learning [33]. Therefore, the AR application developed must meet the needs of students so that they are ready to use it [15].

The findings show that there are hindrances at the moderate level (mean=3.17, $\mathrm{SD}=.652$ ) in the readiness of students to use AR applications. The government is in the process of upgrading the learning environment to be on par with developed countries in the world, which may explain the presence of these moderate hindrances. Learning barriers have been found to have an impact on learning and level of satisfaction at the individual level [34,35]. There are technological barriers (including slow internet access or high computer costs [36]), personality barriers (i.e., the perception that there are barriers), situational barriers (including lack of access), and institutional barriers, including lack of teacher support and instructional design quality. This is in line with prior research that indicates students not only need support, but also need a place to study without interruption [37].

Overall, the results of this study indicate that the barriers to the use of AR applications are at a moderate level, while the level of student readiness is at a high level. Users with high self-readiness will experience fewer obstacles in virtual learning [38]. There appears to be a significant relationship between the barriers to use of AR applications and students' level of readiness to use them with Form 2 Science textbooks in the Malaysian context. These findings provide an important justification for the idea that the future educational environment in Malaysia must take into account the latest technological integration closely related to IR 4.0 and $21^{\text {st }}$-century education. According to the study [39, 40] had been seen that AR application is effective in terms of the academic achievement and has positive contributions to student success and satisfaction. Educational institutions must dare to pursue a paradigm shift and modify elements of the educational environment in terms of curricula and educational infrastructure. Readiness to accept a change, particularly regarding new teaching and learning technology, is important and needs further study.

\section{Acknowledgements}

This study was conducted under the FPend Research Grant [019-2019] and Grant [PP-FPEND-2020]

\section{REFERENCES}

[1] Ministry of Trade and Industry (MITI), National Policy on Industrial 4.0, Government Publication, Kuala Lumpur, 2018.

[2] Ministry of Education (MOE), Malaysia Education Blueprint 2013-2025 Preschool to Post Secondary Schools, KPM, Putrajaya, 2013.

[3] Mohd Sani R., "Pembinaan Kerangka Standart Kompetensi Literasi ICT Kebangsaan: Kajian Delphi,” Kertas bentang di International Seminar on Getting Knowledge Through Research, UUM-UMSIDA. Malaysia: Universiti Utara Malaysia, 2016.

[4] Chiang T.H.C., Yang S., Hwang G.-J., "An Augmented Reality-based Mobile Learning System to Improve Students' Learning Achievements and Motivations in Natural Science Inquiry Activities," Educational Technology and Society, vol. 17, no. 4, pp. 352-365, 2014.

[5] Zamfiroiu A., Despa M.L., "Reasons, Circumstances and Innovative Trends In Mobile Environments," Informatica Economica, vol. 17, no. 2, pp. 109-118, 2013. Doi:10.12948/Issn14531305/17.2.2013.09.2013

[6] Fariza M.S., "Generasi Z dan Isu Perpaduan,” International Colloquium on Integration Platform: Binding Differences and Diversity, Putrajaya, 14-19, 2018.

[7] Lee K., "Augmented Reality in Education and Training," TechTrends, vol. 56, no. 2, 13-21, 2012.

[8] Berryman D.R., "Augmented Reality: A Review," Medical Reference Services Quarterly, vol. 31, no. 2, pp. 212-218, doi:10.1080/02763869.2012.670604, 2012.

[9] Shirazi A., Behzadan A.H., "Content delivery using augmented reality to enhance students' performance in a building design and assembly project," Advances in Engineering Education, vol. 4, no. 3, 2015.

[10] Cikgu H., "Tutorial how to use AR in science text book," https://www.cikguhailmi.com/2018/03/tutorial-guna-AR-pa da-buku-teks-sains.html, 2018.

[11] Bryan R.R., Glynn S.W., Kittleson J.M., "Motivational achievement and advanced placement intent of high school students learning science," Science Education, vol. 95, no. 6, pp. 1049-1065, 2011. DOI 10.1002/sce.20462

[12] Etkin J., Sela A., "How Experience Variety Shapes Post-Purchase Product Evaluation," Journal of Marketing Research, vol. 53, no. 1, 2015. DOI: 10.1509/jmr.14.0175 
[13] Cabero J., Barroso, J., "The Educational Possibilities of Augmented Reality," New Approaches Education Research, vol. 5, pp. 44-50, 2016. https://naerjournal.ua.es/article/vie w/v5n1-7

[14] Shelton B.E., Hedley N.R., "Exploring a Cognitive Basis for Learning Spatial Relationships with Augmented Reality," Technology, Instruction, Cognition and Learning, vol. 1, no. 4, pp. 323-357, 2004.

[15] Mehmet K., Yasin O., "Augmented Reality in Education: Current Technologies and the Potential for Education," Procedia - Social and Behavioral Sciences, vol. 47, pp. 297302, 2012.

[16] Rohaila M.R., Fariza K., "Gamifikasi : Konsep dan Implikasi dalam Pendidikan," Gamifikasi: Konsep dan Implikasi dalam Pendidikan, FPEND, Bangi, 2017.

[17] Khalid F., Wong S.L., "An emic perspective on students' learning experiences using augmented reality," ICCE 2017 25th International Conference on Computers in Education: Technology and Innovation: Computer-Based Educational Systems for the 21st Century, Workshop Proceedings, 2017.

[18] Hanis, A.R., Zanaton H.I., “Aplikasi Augmented Reality (AR) Dan Komik Penceritaan Digital Dalam Pembelajaran Sains," Prosiding Seminar Kebangsaan Pendidikan Negara Kali Ke-5, 805-813, 2015.

[19] Maziah A.M., Harwati H., "Augmented Reality (AR) Based on Approach in Nursing Education: A Preliminary Project," International Journal of Engineering \& Technology, vol. 7, no. 421, pp. 33-36, 2018.

[20] Norhafizah A., “An Interactive Mobile Augmented Reality Text for Book Learning Biology," Journal of Advanced Research in Dynamical and Control Systems, vol. 10, pp. 1719-1725, 2018.

[21] Davis F.D., Bagozzi R.P., Warshaw, P.R., "User Acceptance of Computer Technology: A Comparison of Two Theoretical Models," Management Science, vol. 35, no. 8, pp. 903-1028, 1989. doi:10.1287/mnsc.35.8.982

[22] Im I., Hong S., Kang, M.S., "An International Comparison of Technology Adoption: Testing the UTAUT Model," Information and Management, vol. 48, no. 1, pp. 1-8, 2011. https://doi.org/10.1016/j.im.2010.09.001

[23] Venkatesh V., Morris M.G., Davis G.B., Davis F.D. “User Acceptance of Information Technology: Toward a Unified View," MIS Quarterly, vol. 27, no. 3, pp. 425-478, 2003

[24] Yilmaz R., "Exploring the Role of E-Learning Readiness on Student Satisfaction and Motivation in Flipped Classroom," Computers in Human Behavior, vol. 70, pp. 251-260, 2017.

[25] District Education Department (DED), "Education Data," 2020.

https://www.selangor.gov.my/sepang.php/pages/view/26?m id $=71$

[26] Krejcie R.V., Morgan D.W., "Determining Sample Size for Research Activities," Educational and Psychological Measurement, vol. 30, pp. 607-610, 1970.
[27] Mohd Majid K. "Kaedah penyelidikan pendidikan,” Kuala Lumpur, Dewan Bahasa dan Pustaka, 2005.

[28] Fauzi A.F.A.A., Ali K.N., Amirudin R., "Evaluating Students Readiness, Expectancy, Acceptance and Effectiveness of Augmented Reality Based Construction Technology Education," International Journal of Built Environment and Sustainability, vol. 6, no. 1, pp. 7-13, 2018. DOI 10.11113/ijbes.v6.n1.309

[29] Venkatesh V., Thong J.Y., Xu, X. "Consumer Acceptance and Use of Information Technology: Extending the Unified Theory of Acceptance and Use of Technology." MIS Quarterly, vol. 36, no. 1, pp. 157-178, 2012.

[30] Creswell J.W., Educational Research: Planning, Conducting, and Evaluating Quantitative and Qualitative Research, Pearson, 2008.

[31] Taber K.S. "The Use of Cronbach's Alpha When Developing and Reporting Research Instruments in Science Education," Research in Science Education, vol. 48, pp. 1273-1296, 2018. DOI 10.1007/s11165-016-9602-2

[32] Costin P., "Effects of Gender Differences in the Perceived Learning Quality of an AR-Based Learning Scenario," National Institute for Research and Development in Informatics, Conference Paper, September 2018, Bucharest, Romania.

[33] Smith R., "Richer or Poorer, Better or Worse? How Has the Development of Primary Science Teaching Been Affected by National Curriculum Policy?," The Curriculum Journal, vol. 5, pp. 163-177, 1994.

[34] Giles I.M., "An Examination of Persistence and Dropout in the Online Computer-Conferenced Classroom," Doctoral dissertation, Virginia Polytechnic Institute and State University, UMI No. 9953808, 1999.

[35] Schilke R.A., “A Case Study of Attrition in Web-Based Instruction for Adults: Updating Garland's Model of Barriers to Persistence in Distance Education," Doctoral dissertation, Northern Illinois University, UMI No. 3013802, 2001.

[36] Kramarae C., "The Third Shift: Women Learning Online," AAUW Educational Foundation, 2001.

[37] Pollard E., Hillage J. (Eds.), "Exploring E-Learning," The Institute for Employment Studies, Report No. 376, 2001.

[38] Campeau D.R., Higgins C.A., "Computer Self-Efficacy: Development of a measure and Initial Test," MIS Quarterly, vol. 19 , no. 2 , pp. 189-211, 1995.

[39] Mehmet Fatih Özcan, Âdem Özkan, Nurullah Şahin, "The Influence of the Augmented Reality Application on Students' Performances in Ottoman Turkish Readings," Universal Journal of Educational Research, Vol. 5, No. 12B, pp. 27 - 33, 2017. DOI: 10.13189/ujer.2017.051403.

[40] Demet Somuncuoğlu Özerbaş, "The Effect of Marker-Based Augmented Reality (MBAR) Applications on Academic Achievement and Permanence," Universal Journal of Educational Research, Vol. 7, No. 9, pp. 1926 - 1932, 2019. DOI: 10.13189/ujer.2019.070911 